IZA DP No. 5946

Mothers Do Matter:

New Evidence on the Effect of Parents' Schooling on Children's Schooling Using Swedish Twin Data

Vikesh Amin

Petter Lundborg

Dan-Olof Rooth

August 2011 


\title{
Mothers Do Matter: New Evidence on the Effect of Parents' Schooling on Children's Schooling Using Swedish Twin Data
}

\author{
Vikesh Amin \\ Binghamton University (SUNY) \\ Petter Lundborg \\ Lund University, VU University Amsterdam, Tinbergen Institute, \\ Netspar, HEP and IZA \\ Dan-Olof Rooth \\ Linnaeus University, Lund University, \\ CReAM and IZA \\ Discussion Paper No. 5946 \\ August 2011 \\ IZA \\ P.O. Box 7240 \\ 53072 Bonn \\ Germany \\ Phone: +49-228-3894-0 \\ Fax: +49-228-3894-180 \\ E-mail: iza@iza.org
}

Any opinions expressed here are those of the author(s) and not those of IZA. Research published in this series may include views on policy, but the institute itself takes no institutional policy positions.

The Institute for the Study of Labor (IZA) in Bonn is a local and virtual international research center and a place of communication between science, politics and business. IZA is an independent nonprofit organization supported by Deutsche Post Foundation. The center is associated with the University of Bonn and offers a stimulating research environment through its international network, workshops and conferences, data service, project support, research visits and doctoral program. IZA engages in (i) original and internationally competitive research in all fields of labor economics, (ii) development of policy concepts, and (iii) dissemination of research results and concepts to the interested public.

IZA Discussion Papers often represent preliminary work and are circulated to encourage discussion. Citation of such a paper should account for its provisional character. A revised version may be available directly from the author. 


\section{ABSTRACT}

\section{Mothers Do Matter: New Evidence on the Effect of Parents' Schooling on Children's Schooling Using Swedish Twin Data*}

Behrman and Rosenzweig (2002) used data on a small sample of MZ (monozygotic, identical) twin parents and their children to show that father's schooling is more important than mother's schooling for children's schooling in the U.S. Recent studies based on much larger samples of twins from registry data in Scandinavian countries reach similar conclusions. Most of these studies, however, are unable to distinguish between MZ and DZ (dizygotic, fraternal) twins. Using data from the Swedish Twin Registry, we replicate the finding that father's schooling matters more than mother's schooling in a combined sample of $M Z$ and DZ twin parents. In contrast, results based on MZ twin parents show that mother's schooling matters at least as much as father's schooling for children's schooling. We also estimate the effect of parents' schooling separately by child gender and find this effect to be entirely driven by the impact of mother's schooling on daughter's schooling. Our results show that (1) it is vital to have zygosity information to estimate causal intergenerational effects and (2) the conclusions reached by Behrman and Rosenzweig (2002) for the U.S. do not apply in Sweden.

JEL Classification: J0, 10, J1

Keywords: $\quad$ twins, twin-fixed effects, schooling, intergenerational mobility

Corresponding author:

Dan-Olof Rooth

Linnaeus School of Business and Economics

Linnaeus University

Kalmar Nyckel

SE-39182 Kalmar

Sweden

E-mail: dan-olof.rooth@Inu.se

\footnotetext{
* We thank Jere Behrman, Lars Kirkebøen, Erik Plug, and Maria Stanfors for useful comments. A research grant from the Centre for Economic Demography at Lund University is gratefully acknowledged.
} 


\section{Introduction}

There is a strong intergenerational association between parental schooling and children's schooling. This association does not necessarily reflect a causal relationship, due to the influence of unobserved endowments that affect both parents' and children's schooling. For example, parents with higher innate ability will obtain more schooling and have more able children who obtain more schooling. In order to account for such unobserved endowments, a small number of studies use data on twin parents and their children to estimate the causal effect of parents' schooling on children's schooling. These studies use the within-twins (or equivalently twins fixedeffects) approach, which relates schooling differences between parents who are twins to schooling differences between their children who are cousins. This approach exploits the assumption that twin parents have identical innate endowments, so that unobserved endowments which would bias the cross-sectional association are removed within twin pairs.

Results from the within-twins approach generally indicate that (1) estimates of the causal effect of parents' schooling are smaller than the cross-sectional associations and (2) father's schooling is more important than mother's schooling. The first paper to find this pattern was Behrman and Rosenzweig (2002), who used data on MZ (monozygotic, identical) twin parents from the Minnesota Twin Registry in the U.S. They found that an additional year of father's schooling increases children's schooling by 0.36 of a year, but found no significant effect of mother's schooling. ${ }^{1}$

A number of recent studies using Scandinavian data, with much larger samples of twin parents, have replicated the finding of Behrman and Rosenzweig (2002). In Holmlund et al. (2010), an additional year of father's schooling was found to increase Swedish children's schooling by 0.11 years, whereas the effect of mother's schooling was small and statistically insignificant. Similar findings were reported in Norway by Pronzato (2010), where the effect of father's schooling was 0.16. Pronzato (2010)

\footnotetext{
${ }^{1}$ Antonovics and Goldberger (2005) argue that the results from Behrman and Rosenzweig (2002) are not robust to alternative coding schemes for schooling and alternative sample selection criteria. Behrman and Rosenzweig (2005) contest Antonovics and Goldberger's recoding and show that their results are robust to an independent coding scheme. Moreover, in a very narrow sample restricted to MZ twins parents, with children aged 18 or over, all having finished school, Antonovics and Goldberger find a significant effect of father's schooling of 0.40 and no significant effect for mother's schooling.
} 
does, however, find a significant effect of mother's schooling of 0.10 . Haegeland et al. (2010) study the relationship between parents' schooling and children's test scores in Norway and also find greater point estimates for father's schooling than for mother's schooling although both were statistically insignificant.

The studies by Holmlund et al. (2010), Pronzato (2010), and Haegeland et al. (2010) all use registry data where it is impossible to separate between MZ and DZ (dizygotic, fraternal) twins. Unlike MZ twins, DZ twins are like non-twin siblings and only share one half of their innate endowments. This means that the within-twins approach will not fully control for the influence of unobserved endowments in a combined sample of $\mathrm{MZ}$ and DZ twin parents. If there is no measurement error in schooling, then estimates from a sample that includes both MZ and DZ twin parents will be biased upwards. It therefore remains unclear to what extent these replications of Behrman and Rosenzweig's result are biased by unobserved endowments that are not differenced out in a combined sample of $\mathrm{MZ}$ and $\mathrm{DZ}$ twin parents.

Some indications of the possible bias arising from using pooled samples of MZ and DZ twin parents are given in a recent working paper by Bingley et al. (2009), where they are able to distinguish between MZ and DZ twins. Based on MZ twin parents, they find that father's schooling is more important than mother's schooling in Denmark. For MZ twin parents born after 1945, however, they find that the effect of mother's schooling increases, while the effect of father's schooling decreases. Similar conclusions are also reached based on DZ twin parents. Since they do not compare results obtained by using pooled MZ and DZ twin parents with those obtained using MZ twin parents only, their results do not reveal the potential bias reflected in the previous twin-based studies using Scandinavian data.

We contribute to the literature in mainly two ways. First, using data from the Swedish Twin Registry, we replicate the finding that father's schooling matters more than mother's schooling in a combined sample of $\mathrm{MZ}$ and $\mathrm{DZ}$ twin parents. In contrast, based on MZ twin parents only, we find that mother's schooling matters at least as much as father's schooling. Second, we provide for the first time estimates of the effect of parents' schooling on son's and daughter's schooling using the withintwins approach. We find that the effect of mother's schooling on children's schooling is entirely driven by the effect of mother's schooling on daughter's schooling.

In addition, we make some attempts to understand the mechanisms underlying our results. We are able to rule out a number of explanations for the greater effect of 
mothers' schooling, such as gender differences in measurement error, fertility behavior, assortative mating, and social interactions. Instead, our results are in line with recent findings suggesting that well-educated mothers spend more time with their children than high-educated fathers. We also speculate that the differences between our results for Sweden and previous results for the U.S. reflect institutional differences regarding maternity leave and childcare that affects child development, and possible strength of role model effects. Finally, we are able to rule out some explanations for the finding that the estimate change more for fathers than for mothers when moving from our pooled sample of MZ and DZ twins to our sample of $\mathrm{MZ}$ twins, such as a greater genetic contribution to schooling among fathers than mothers.

In sum, our results show that (1) it is vital to have zygosity information in order to estimate the causal effect of parents' schooling on children's schooling, given the different conclusions reached from using the combined $\mathrm{MZ}$ and DZ twin parents sample to using the MZ sample and (2) the conclusions reached by Behrman and Rosenzweig (2002) on U.S. data do not apply in Sweden.

\section{Methodology}

Consider a reduced-form intergenerational mobility model where the schooling of child $\mathrm{i}$ in family $\mathrm{j}\left(\mathrm{S}_{\mathrm{ij}}^{\mathrm{c}}\right)$ is related to his/her mother's schooling $\left(\mathrm{S}_{\mathrm{j}}^{\mathrm{m}}\right)$, father's schooling $\left(S_{j}^{f}\right)$, unobserved innate endowments of the mother and father $\left(h^{m}{ }_{j}\right.$ and $\left.h_{j}^{f}\right)$, unobserved child-rearing endowments of the mother and father $\left(f^{m}{ }_{j}\right.$ and $\left.f_{j}^{f}\right)$ and a child-specific stochastic term $\left(\varepsilon^{c}{ }_{i j}\right)$

$S_{i j}^{c}=\beta^{m} S^{m}{ }_{j}+\beta^{f} S_{j}^{f}+h^{m}{ }_{j}+h_{j}^{f}+f^{m}{ }_{j}+f_{j}^{f}+\varepsilon^{c}{ }_{i j}$

An OLS regression of relation (1) provides an estimate of the intergenerational association between parents' and children's schooling, which is a biased estimate of the causal intergenerational effect, because parents' schooling is related to the unobserved innate and child-rearing endowments that also directly affect children's schooling. The influence of these unobserved endowments can be controlled for in the within-twins approach, which relates schooling differences between children who are cousins to schooling differences between parents who are twins and to differences in parental unobserved innate and child-rearing endowments. 
$\Delta S_{j}^{c}=\beta^{m} \Delta S^{m}{ }_{j}+\beta^{f} \Delta S_{j}^{f}+\Delta h^{m}{ }_{j}+\Delta h_{j}^{f}+\Delta f^{m}{ }_{j}+\Delta f_{j}^{f}+\Delta \varepsilon_{j}^{c}$

Relation (2) can be estimated separately for twin mothers and twin fathers. In the case of MZ twin mothers, the unobserved endowments $\Delta \mathrm{h}^{\mathrm{m}}{ }_{\mathrm{j}}$ and $\Delta \mathrm{f}^{\mathrm{m}}{ }_{\mathrm{j}}$ will be completely differenced out, as MZ twins are genetically identical and share the same family environment. ${ }^{2}$ For DZ twin mothers, these unobserved endowments will not be fully differenced out, as DZ twins are not genetically identical. For twin mothers, relation (2) also does not difference out the unobserved endowments of the spouse, in this case $\Delta \mathrm{h}_{\mathrm{j}}^{\mathrm{f}}$ and $\Delta \mathrm{f}_{\mathrm{j}}^{\mathrm{f}}$, as the spouse's are (usually) not twins. Given assortative mating in the marriage market, the unobserved endowments of twin mothers will be correlated with the unobserved endowments of non-twin fathers. The inclusion of schooling differences between non-twin fathers will reduce the effect of unobserved endowments of the father that affect the estimate of mother's schooling.

\section{Data}

Our empirical analysis is based on a data set constructed by integrating registers from Statistics Sweden (SCB) and the Swedish Twin Registry. The former is the base source and contains information on the Swedish population being 16-64 years old in 1999. Data on children's education, in terms of years of schooling, is taken from a 2007 update, while parents' years of schooling is from the 1999 register. This data also links parents to children, including information on whether the parent is a twin and also who his/her twin sibling is. Given the data we have information on twin parents born 1925-1965 and their children born 1945-1983. Zygosity has been determined for 82 percent of the individuals in our dataset, based on survey questions regarding co-twin similarity. The method used has been found to classify twins with an accuracy of 95 percent or more (see Lichtenstein et al., 2002). Our dataset includes 8,568 twin parental pairs, of which 3,225 are (classified as) MZ. Educational attainment is expressed in terms of the highest degree attained. Our measure of years

\footnotetext{
${ }^{2}$ The effect of mother's schooling is identified by MZ twin mothers who have different levels of schooling. Bound and Solon (1999) have posed the question that if MZ twins are truly identical, why do they ever display schooling differences. If schooling differences between MZ twin mothers are due to factors that also directly affect their children's schooling, then the within-twins estimate in relation (2) of $\beta^{\mathrm{m}}$ will be biased.
} 
of schooling is assigned based on the standard number of years of schooling associated with this degree.

\section{Results}

One of our aims is to understand whether estimates of the effects of parents' schooling obtained from a combined sample of $\mathrm{MZ}$ and $\mathrm{DZ}$ twin parents differ substantially from those obtained by using MZ twin parents only. Table 1 first provides summary statistics for our pooled sample of MZ and DZ twin parents and MZ twin parents only. The distribution of birth cohorts (for both twin parents and children) is the same in both samples. Average years of schooling for children, twin parents and spouses is slightly higher in the MZ twin parents sample compared to the combined $\mathrm{MZ}$ and $\mathrm{DZ}$ twin parents sample.

In order to facilitate a comparison to previous results in the literature, Table 2 reports intergenerational associations (OLS) and effects (within-twins) in years of schooling for a combined sample of $\mathrm{MZ}$ and $\mathrm{DZ}$ twin parents and their children. The estimated intergenerational associations, shown in columns 1 and 2 of panel A, are about 0.24 for both mothers and fathers. In Column 3, which restricts the effect of father's and mother's schooling to be equal, the estimated effect of parental schooling is also 0.24. These OLS estimates are very similar to those obtained in Holmlund et al. (2010) and Pronzato (2010). The estimated intergenerational associations fall to 0.17 when spousal years of schooling are controlled for. We also estimate the effect of parents schooling by child gender. In panels B and C, there is some evidence that father's (mother's) schooling matters more for son's (daughter's) schooling.

In comparison, the intergenerational effects in columns 4 to 6 , which attempt to control for the influence of unobserved endowments, are smaller than the intergenerational associations. In line with the previous literature, we also find that father's schooling matters more than mother's schooling. One additional year of father's and mother's schooling increases the child's schooling by 0.12 and 0.06 years, respectively, when controlling for spousal education. These estimates are very similar to those obtained by Holmlund et al. (2010) of 0.11 and 0.04 for their pooled sample of MZ and DZ Swedish twin parents.

The difference in the intergenerational effects between mothers and fathers becomes even more pronounced when we examine the effect on sons and daughters separately. The effect of father's schooling on son's schooling is triple the size of 
mother's schooling when controlling for spousal education. The effect of father's schooling on daughter's schooling is also larger, but not significantly different from mother's schooling. Although the estimates of mother's schooling are smaller than the estimates for father's schooling, they are significant at the one percent level. This contrasts to most of the previous studies that generally find insignificant effects of mother's schooling, which perhaps can be explained by the much larger sample size exploited in our data.

Table 3 reports results exclusively for MZ twin fathers and mothers and their children. Again there are strong intergenerational associations between father's and mother's schooling and their children's schooling. The magnitudes of the intergenerational associations are very similar to the corresponding magnitudes obtained in our sample of MZ and DZ twin parents. Controlling for more unobserved endowments using MZ twin parents also produces intergenerational effects that are smaller than the intergenerational associations. The intergenerational effects of father's schooling are now, however, substantially smaller than those obtained from the combined MZ and DZ twin parents sample in Table 2. For example, the effect of father's schooling on children's schooling was 0.12 based on MZ and DZ twin fathers (when controlling for spousal education) but is now only 0.05 when we restrict the sample to MZ twin fathers. In comparison, there is no such change in the estimated effect of mother's schooling, which is 0.06 in column 5 in both Tables 2 and 3. Mother's schooling is now at least as important as father's schooling for children's schooling and both the effects of mother's and father's schooling are significant. The results in panel B suggest that neither father's nor mother's schooling significantly affect son's schooling when accounting for spousal schooling. Moreover, there is no significant effect of father's schooling on daughter's schooling in panel $\mathrm{C}$, whereas one additional year of mother's schooling increases daughter's schooling by 0.10 of a year. ${ }^{3}$ Restricting the sample to $\mathrm{MZ}$ twin parents thus provides results that are

\footnotetext{
${ }^{3}$ Three other studies estimate the effects of parents' schooling separately by child gender. Black et al. (2005) find that mother's schooling matters for son's schooling, but not for daughter's schooling, with these results being based on IV estimates using changes in compulsory schooling leaving laws in Norway. Chevalier (2003) finds that mother's schooling effects daughter's schooling but not son's schooling using IV estimates for the U.K. Ermisch and Pronzato (2010) also find the same as Chevalier (2003) for Norway using the within-siblings approach.
} 
substantially different from those obtained from the pooled sample of $\mathrm{MZ}$ and DZ twin parents in Table 2 .

How stable are our estimates over time? The labor force participation rate of women in the Swedish labor market increased during the creation of the Swedish welfare state. In 1965 the labor force participation rate was 54 percent, which increased to 82 percent by 1990 (see Stanfors, 2007, Table 3.2). ${ }^{4}$ To further investigate to what extent this entrance of Swedish women in the labor market is related to the positive effect of mother's schooling found above, we divide the data into two time periods. To this end, Table 4 reports intergenerational effects separately for MZ twin parents born 1925-1939 and born 1940-1965. ${ }^{5}$ The results in panel A show the effect of parents' schooling on children's schooling has decreased over time. In the pre-1940 cohorts an extra year of father's or mother's schooling increased children's schooling by 0.10 of a year. However in the post-1940 cohorts there is no significant effect of father's or mother's schooling. This may reflect increased opportunities to attend higher education over time, which coincides with the expansion of labor force participation of women. A similar conclusion is reached in panel B, where both mother's and father's schooling affected the son's schooling in the pre-1940 cohorts, but no such effects remain in the post-1940 cohorts. In contrast, the effect of mother's schooling on daughter's schooling is very robust over time. In both the pre-1940 cohorts and the cohorts born 1940-1965, an additional year of mother's schooling increases the daughter's schooling by about 0.10 of a year. This finding indicates that Swedish women's entrance in the labor market may have positively have affected their daughter's investment in schooling, an issue we will return to in the next section. The insignificant results for fathers in the later cohorts do not seem to be driven by sample size, as there are more twin pairs with schooling differences in the post-1940 cohorts compared to the pre-1940 cohorts.

\footnotetext{
${ }^{4}$ The corresponding figures for men are 89 and 87 percent, respectively.

${ }^{5}$ Table A1 in the Appendix also reports intergenerational effects for MZ and DZ twin parents born 1925-1939 and born 1940-1965. The results show that the importance of father's schooling has fallen over time, but remains more important than mother's schooling over time. This again illustrates that it is vital to have information on zygosity to separate out MZ and DZ twins, since the results obtained for MZ twin parents show that mother's schooling is at least as important as father's schooling in the post1940 cohorts.
} 
In summary, our results based on $\mathrm{MZ}$ twin parents and their children suggest that mother's schooling is at least as important as father's schooling for children's schooling. Our results clearly illustrate the importance of having access to zygosity information, since the results change dramatically when restricting the sample to $\mathrm{MZ}$ twins. Moreover, our finding that mother's schooling matters at least as much as father's schooling, appears to be driven by the effect of mother's schooling on daughter's schooling. Since the within-twins approach controls for unobserved endowments that affect both parents' and children's schooling, the differential effect of mother's schooling on son's and daughter's schooling, may suggest that the unobserved endowments of the mother are more strongly correlated with son's schooling compared to daughter's schooling.

\section{Discussion}

Our analyses so far raise a number of questions. First of all, and perhaps most importantly, why does mothers' schooling appear to matter at least as much or more than fathers' schooling in Sweden? Second, why do our results differ from those obtained in the U.S, where fathers' schooling is found to matter more than mothers' schooling? Third, why do our estimates for the sample of MZ twins differ from our estimates for the pooled sample of MZ and DZ twins? In this section, we address these three questions, with the main focus on the first question, which we believe is the most important one.

(1) Why does mothers' schooling appear to matter at least as much or more than fathers' schooling in Sweden?

We first consider possible gender differences in measurement error in parents' schooling. A purely mechanical explanation for the finding that mother's schooling matters at least as much or more than father's schooling would be that the estimated intergenerational effects for $\mathrm{MZ}$ twin fathers suffer from a greater attenuation bias than the corresponding effects for mothers, due to more severe measurement error in schooling for fathers. In the within-twins design, the attenuation bias depends both upon the reliability ratio and the correlation between schooling levels of the twins. ${ }^{6}$

\footnotetext{
${ }^{6}$ Assume that measured schooling $\left(\mathrm{S}_{\mathrm{ij}}\right)$ is linearly related to true schooling $\left(\mathrm{S}_{\mathrm{ij}}\right)$ but is measured with random measurement error $\mathrm{w}_{\mathrm{ij}}$ : $\mathrm{S}_{\mathrm{ij}},=\mathrm{S}_{\mathrm{ij}}+\mathrm{w}_{\mathrm{ij}}$. Then the within-twin intergenerational effect is biased
} 
We do not expect such differential measurement error by gender to be driving the results for two reasons. First, the schooling data is based on register information and not on self-reports. Holmlund et al. (2008) report that the reliability ratio for fathers and mothers is 0.95 , using Swedish register data. Second, the correlation in schooling for $\mathrm{MZ}$ twin fathers and mothers is also the same, at about 0.68 , in our data, which, together with the reliability ratio, means that any attenuation bias should be the same for mothers and fathers.

A more direct explanation for our finding that mother's schooling matters more would be that more educated mothers spend more time with their children. We do not have time use data for our sample, but results from previous studies may shed some light on this issue. Ichino and Sanz de Galdeano (2005) found that well-educated mothers in Sweden spend more time with their children than well-educated fathers. Guryan et al. (2008) also show this to be the case in the U.S. and in many other Western countries. As we find that mother's schooling is more important for daughters, this could suggest that mothers spend more time with daughters than sons. Alternately, this could suggest that highly educated mothers serve as a role model for their daughters, who aim to be highly educated like their mothers.

There are also possible indirect mechanisms that would generate a pattern where mother's schooling appears to be more important. Such a pattern could arise if highly educated women have fewer children of higher quality but that this does not apply to highly educated fathers. We can check this by running within-twins regressions on the relationship between schooling and the number of children for both twin mothers and twin fathers. Columns 1 and 2 in Appendix Table A2 indicate that there is no significant relationship between mother's and father's schooling and the number of daughters. Since we only obtained a significant effect of mother's schooling on daughter's schooling, we can thus rule out possible gender differences in the qualityquantity trade off as an explanation for our finding. ${ }^{7}$

The greater effect of mother's schooling may also be driven by gender differences in assortative mating, where the role of the spouse's characteristics may differ between twin mothers and twin fathers. Our intergenerational effects only

downwards by: $\sigma^{2}\left(\mathrm{w}_{\mathrm{ij}}\right) /\left(\sigma^{2}\left(\mathrm{~S}_{\mathrm{ij}}\right)\left(1-\rho_{\mathrm{S}}\right)\right)$. Where $\rho_{\mathrm{S}}$ is the correlation in schooling levels between the twins and $\sigma^{2}\left(\mathrm{w}_{\mathrm{ij}}\right) / \sigma^{2}\left(\mathrm{~S}_{\mathrm{ij}}\right)$ is the reliability ratio.

${ }^{7}$ There is however, a very small, -0.027 , and significant negative relation between mother's schooling and the number of sons. 
partially control for assortative mating, because unobserved endowments of the spouse are not differenced out in the within-twins approach. The positive effect of mother's schooling may therefore instead reflect positive traits of the spouse that are correlated with the twin mother's schooling. In addition, well-educated mothers are perhaps able to attract high ability spouses to a greater extent than well-educated fathers. Some suggestive evidence of such a pattern would be if there is a stronger correlation between the schooling of twin mothers and the schooling of their spouses than between the schooling of twin fathers and their spouses. One would then probably also expect that the schooling of twin mothers is more strongly correlated with other unobserved, traits of the spouse, besides schooling, which we are not able to control for. Column 3 in Appendix Table A2 shows that mothers with more schooling, indeed, have higher educated husbands. This is, however, also the case for twin fathers, as shown in Column 4. In fact, the estimates are very similar, which does not provide any evidence that twin mothers' schooling is more strongly correlated with positive traits of the spouse. Although the correlation in schooling between twin parents and their spouses is similar across twin mothers and twin fathers, there may be other unobserved traits of the spouse that are more strongly correlated with the schooling of twin mothers.

Another such potentially important trait would be the unobserved child-rearing endowments of the spouse. Child-rearing skills are usually assumed to be more important among mothers, which would lead to an upward bias in the estimated effect of twin father's schooling, since differences in the spouse's child-rearing skills are not differenced out. Assuming that child-rearing skills matter less for fathers, this upward bias would not occur to the same extent among twin mothers. This explanation is therefore also unlikely to drive our result that twin mothers' schooling matters more.

Finally, the difference in effects between mother's and father's schooling could also be explained by differences in social interactions across genders. As discussed by Ermisch and Pronzato (2010), social interactions between the children of twin parents will tend to diminish the differences in schooling attainment between them, resulting in smaller estimates of the effect of parents' schooling. Moreover, twin parents may interact more than other parents, also creating increased similarity among them. Since it is usually assumed that females interact more than males, we do not believe that differences in social interactions between genders can explain our results. 
We are able to rule out a number of possible explanations for our findings, such as gender differences in measurement error, fertility behavior, assortative mating, and social interactions. Instead, we believe that the most credible explanation for our finding is that mothers seem to spend more time with their children compared to fathers. This is supported by findings both for Sweden and for many other Western countries, although these findings are of a descriptive character.

(2) Why are our results so different from those obtained by Behrman and Rosenzweig (2002) for the U.S.?

We can only speculate on the reasons for the U.S. - Sweden differences and hence, our goal is not to present a definitive answer. One possible reason why mother's schooling matters in Sweden but not in the U.S. relates to the negative consequences of short maternity leave and maternal employment during the first year on children's development. Baum (2003) reports that over a third of new mothers who worked during pregnancy return to work within 3 months of childbirth in the U.S. His results show that maternal work in the first year has negative effects on child cognitive development. This is less likely to be a concern in Sweden, as mothers were entitled to about 12 months of paid maternity leave. Even when mothers do return to work in Sweden, most children attend high quality childcare centres, which means that any negative effect of less time spent with their children may be offset by a positive effect of high-quality childcare. In line with this, Havnes and Mogstad (2011) find that the expansion of subsidized childcare in Norway had a strong positive effect on children's long run educational attainment. ${ }^{8}$ In the U.S., on the other hand, Herbst and Tekin (2010) show that publicly subsidized childcare has negative effects on children's cognitive ability in kindergarten and that the adverse effects are largely concentrated among children of highly educated mothers.

Another, admittedly highly speculative, explanation is that in the U.S., a higher fraction of highly educated women opt out of the labour market in order to take care of family responsibilities. Although highly educated, such housewives may be less likely to serve as role models for their daughters. For example, Goldin (1992) argues

\footnotetext{
${ }^{8}$ We are not aware of any studies that estimate the causal effect of childcare on children's outcome in Sweden. The results for Norway are likely to be similar to Sweden, as the countries share many common institutional factors, such as subsidized childcare.
} 
that the main motive of acquiring a college education for women was the higher probability of marrying a college educated man. Neal (2004) also notes "married women who are raising children account for a disproportionate share of white women who do not work, and a noteworthy number of these women are married to men who earn relatively high incomes" (pg S3).

(3) Why are our results for MZ twin so different from our results obtained for the pooled sample of $M Z$ and DZ twins?

In the regressions using the pooled sample of MZ and DZ twins, genetic endowments are not fully differenced out, since DZ twins only share 50 percent of their genes. One simple reason for the greater effect of father's schooling obtained in this sample may be that there is a stronger genetic component to father's schooling than mother's schooling. This would be consistent with the pattern obtained when moving from the $\mathrm{MZ}$ and DZ twin parents sample to the MZ sample (from Table 2 to 3), where the effect of father's schooling falls towards zero in the MZ twin parents sample but the effect of mother's schooling changes very little. We are able to check if there is a greater genetic component to fathers' schooling, using classical twin geneenvironment decomposition techniques. We find that the variance in schooling due to genes is very similar for fathers and mothers, 40 and 34 percent respectively. ${ }^{9}$ Hence gender differences in the genetic contribution to schooling do not explain our results.

The fact that the genetic component to schooling is similar across mothers and fathers suggests that there is something else going on when moving from our combined sample of $\mathrm{MZ}$ and $\mathrm{DZ}$ twins to our sample of $\mathrm{MZ}$ twins. A natural way to interpret the change in results for fathers is that there is some genetic endowment that is correlated with father's schooling (and their children's schooling) that is not differenced out in the sample of DZ twins but that is then differenced out in our sample of MZ twins. One candidate would be earnings endowments, assuming that father's income is more important for children's schooling than mother's income. This would mean that the effect of father's schooling is upward biased in the sample of DZ fathers, due to omitted earnings endowments. We can check if this is a likely explanation by adding income (taken from the tax registers) as an additional covariate

\footnotetext{
${ }^{9}$ The variance in schooling due to genes is calculated as $2\left(r_{\mathrm{mz}}-\mathrm{r}_{\mathrm{dz}}\right)$ where $\mathrm{r}_{\mathrm{mz}}$ and $\mathrm{r}_{\mathrm{dz}}$ are the schooling correlations between MZ and DZ twins respectively.
} 
to our regressions. Doing so reveals that unobserved earnings endowments are not a likely explanation for our findings for father's schooling, since the effect of schooling changes very little when adding income to the regressions (results available on request).

Summing up, we are not able to provide any definitive answer to the question why the results for fathers' schooling change when moving from the combined sample of MZ and DZ twins. Besides income, which we could rule out, there may be many other unobserved traits that are correlated more strongly with the schooling of the fathers than the mother and that affects the children's schooling. The advantage of the $\mathrm{MZ}$ twin design, however, is that we do not need to know exactly what those traits are in order to cancel out their influence.

\section{Summary}

Our results show that the conclusion that mother's schooling does not matter for their children's schooling, reached in the seminal paper by Behrman and Rosenzweig (2002) for the U.S., does not apply in Sweden. Most previous studies that have replicated the findings of Behrman and Rosenzweig in a Scandinavian context have been unable to separate out MZ twins in the data and it has been argued that this does not matter for the conclusions reached. Based on a combined sample of MZ and DZ twin parents and their children, we indeed replicate the finding that father's schooling matters more than mother's schooling. In contrast, focusing only on MZ twin parents and their children, we find that mother's schooling matters at least as much as father's schooling for children's schooling. ${ }^{10}$ Being able to differentiate between the effect for sons and daughters, we find this effect to be entirely driven by the impact of mother's schooling on daughter's schooling. Moreover the effect of parents' schooling has decreased over time, with the exception of the effect of mother's schooling on daughter's schooling which has remained stable. It is therefore vital to

\footnotetext{
${ }^{10}$ Other research designs being used to estimate the causal effect of parents' schooling on children's schooling are the adoption and the instrumental variables designs. Holmlund et al. (2011) contrast the causal schooling effect arising from these different methods when applied to the same data sources. In accordance with our result, they find that mother's schooling is more important than father's schooling when using an arguably exogenous change in compulsory schooling. On the contrary, using data on adopted children and their adoptive parents they find that father's schooling is more important than mother's schooling.
} 
have zygosity information to estimate causal intergenerational effects, given our differing conclusions reached from the combined sample of MZ and DZ twin parents and the sample of MZ sample. We do not know the exact reasons why mother's schooling does not matter in the U.S., but does so in Sweden. We speculate that this could be due to (1) institutional differences regarding maternity leave and childcare that affects child development and (2) possible strength of role model effects. Understanding why mother's schooling matters in Sweden, using data on MZ twin parents and their children for identification but not in the US is an avenue for further research. 


\section{References}

Antonovics, Kate and Arthur S. Goldberger (2005), "Does Increasing Women's

Schooling Raise the Schooling of the Next Generation? Comment", American Economic Review, 95:5, pp. 1738-1744.

Baum II, Charles (2003), "Does Early Maternal Employment Harm Child Development? An Analysis of the Potential Benefits of Leave Taking", Journal of Labor Economics, 21:2, pp. 409-408.

Behrman, Jere R. and Mark R. Rosenzweig (2002), "Does increasing women's schooling raise the schooling of the next generation?" American Economic Review, 92:1, pp. 323-334.

Behrman, Jere R. and Mark R. Rosenzweig (2005), "Does increasing women's schooling raise the schooling of the next generation?-Reply" American Economic Review, 95:5, pp. 1745-1751.

Bingley, Paul, Kaare Christensen and Vibeke Jensen (2009), "Parental Schooling and Child Development: Learning from Twin Parents", SFI WP 07:2009.

Black, Sandra, Devereux, Paul and Kjell Salvanes (2005), "Why the Apple Doesn't Fall Far: Understanding Intergenerational Transmission of Human Capital", American Economic Review, 95:1, pp. 437-499.

Bound, John and Gary Solon (1999), "Double Trouble On the Value of Twins-Based Estimation of the Return to Schooling", Economics of Education Review, 18:2, pp. 169-182.

Chevalier, Arnaud (2004), "Parental Education and Child's Education: A Natural Experiment”, IZA Discussion Paper Number 1153.

Ermisch, John, Pronzato, Chiara. (2010), "Causal Effect of Parents' Education on Children's Education." ISER Working Paper No. 2010-1 
Goldin, Claudia (1992), "The meaning of college in the lives of American women: The past one-hundred years", NBER Working Paper No. 4099.

Guryan, Jonathan, Erik Hurst and Melissa Kearing (2008), "Parental Education and Parental Time with Children”, Journal of Economic Perspectives, 22:3, pp. 23-46.

Hægeland, Torbjørn, Lars Kirkebøen, Oddbjørn Raaum and Kjell Salvanes (2010), "Why Children of College Graduates Outperform their Schoolmates: A study of Cousins and Adoptees." Mimeo, University of Bergen.

Havnes, Tarjei and Magne Mogstad (2011), "No Child Left Behind: Subsidized Childcare and Children's Long-Run Outcomes", American Economic Journal: Economic Policy, American Economic Association, 3:2, pp.97-129

Herbst, Chris A. and Erdal Tekin (2010), "Child care subsidies and child development", Economics of Education Review, 29:4, pp.618-638.

Holmlund, Helena, Mikael Lindahl and Erik Plug (2008), "The Causal Effect of Parents' Schooling on Children's Schooling: A Comparison of Estimation Methods", IZA DP No. 3630.

Holmlund, Helena, Mikael Lindahl and Erik Plug (2010), "The Causal Effect of Parents' Schooling on Children's Schooling: A Comparison of Estimation Methods", Journal of Economic Literature, forthcoming.

Ichnio, Andrea and Anna Sanz de Galdeano (2005), "Reconciling Motherhood and Work: Evidence from Time-Use Data in Three Countries", in The Economics of Time Use. Daniel Hammermesh and Gerad Pfann, eds. Amsterdam: North-Holland.

Lichtenstein, P., De Faire, U., Floderus, B., Svartengren, M., Svedberg, P., \& Pedersen, N. L. (2002). The Swedish 2007-04-27 21 Twin Registry: A unique resource for clinical, epidemiological and genetic studies. Journal of Internal Medicine, 252, 184-205. 
Neal, Derek (2004), “The measured Black-White Wage Gap among Women Is Too Small”, Journal of Political Economy, 112, S1-S28.

Pronzato, Chiara (2010), “An Examination of Paternal and Maternal Intergenerational Transmission of Schooling”, Journal of Population Economics, forthcoming.

Stanfors, M. (2007) Mellan arbete och familj. Ett dilemma för kvinnor i 1900-talets Sverige. SNS Förlag, Stockholm, Sweden. 
Table 1 . Summary statistics.

\begin{tabular}{|c|c|c|}
\hline & $\begin{array}{c}M Z+D Z \\
\text { (1) }\end{array}$ & $\begin{array}{c}\mathrm{MZ} \\
(2)\end{array}$ \\
\hline \multicolumn{3}{|l|}{ Sons: } \\
\hline Years of schooling & $12.24(2.18)$ & $12.31(2.13)$ \\
\hline \multicolumn{3}{|l|}{ Year of birth: } \\
\hline $1945-1955$ & 0.08 & 0.07 \\
\hline $1956-1965$ & 0.27 & 0.25 \\
\hline $1966-1975$ & 0.41 & 0.41 \\
\hline $1975-1983$ & 0.24 & 0.27 \\
\hline \multicolumn{3}{|l|}{ Daughters: } \\
\hline Years of schooling & $12.73(2.15)$ & $12.79(2.14)$ \\
\hline \multicolumn{3}{|l|}{ Year of birth: } \\
\hline $1945-1955$ & 0.08 & 0.07 \\
\hline $1956-1965$ & 0.28 & 0.27 \\
\hline 1966-1975 & 0.40 & 0.40 \\
\hline $1975-1983$ & 0.24 & 0.26 \\
\hline \multicolumn{3}{|l|}{ Twin fathers: } \\
\hline Years of schooling & $10.48(3.06)$ & $10.61(3.05)$ \\
\hline \multicolumn{3}{|l|}{ Year of birth: } \\
\hline $1925-1935$ & 0.26 & 0.25 \\
\hline $1936-1945$ & 0.42 & 0.42 \\
\hline $1946-1955$ & 0.30 & 0.31 \\
\hline $1956-1965$ & 0.02 & 0.02 \\
\hline Wife years of schooling & $10.85(2.78)$ & $10.85(2.75)$ \\
\hline \multicolumn{3}{|l|}{ Twin mothers: } \\
\hline Years of schooling & $10.21(2.77)$ & $10.54(2.85)$ \\
\hline \multicolumn{3}{|l|}{ Year of birth: } \\
\hline $1925-1935$ & 0.28 & 0.25 \\
\hline $1936-1945$ & 0.37 & 0.38 \\
\hline 1946-1955 & 0.31 & 0.33 \\
\hline $1956-1965$ & 0.04 & 0.04 \\
\hline Husband years of schooling & $10.45(3.05)$ & $10.69(3.10)$ \\
\hline
\end{tabular}


Table 2. Intergenerational associations/effects in years of schooling. Mono- and dizygotic twins. Years of schooling as of 2007 for children. Parents born 1925-65 and children born 1945-1983.

\begin{tabular}{|c|c|c|c|c|c|c|c|}
\hline & \multirow{2}{*}{$\begin{array}{c}\text { Controlling for } \\
\text { spouse's schooling }\end{array}$} & \multicolumn{3}{|c|}{ Intergenerational associations } & \multicolumn{3}{|c|}{ Intergenerational effects } \\
\hline & & $\begin{array}{l}\text { Father } \\
(1)\end{array}$ & $\begin{array}{l}\text { Mother } \\
(2)\end{array}$ & $\begin{array}{l}\text { Father+Mother } \\
\text { (3) }\end{array}$ & $\begin{array}{l}\text { Father } \\
(4)\end{array}$ & $\begin{array}{l}\text { Mother } \\
(5)\end{array}$ & $\begin{array}{c}\text { Father+Mother } \\
\text { (6) }\end{array}$ \\
\hline \multirow[t]{3}{*}{ A. Sons+daughters } & no & $\begin{array}{c}0.237 * * * \\
(0.006)\end{array}$ & $\begin{array}{c}0.236 * * * \\
(0.006)\end{array}$ & $\begin{array}{c}0.237 * * * \\
(0.004)\end{array}$ & $\begin{array}{c}0.148 * * * \\
(0.013)\end{array}$ & $\begin{array}{c}0.083 * * * \\
(0.012)\end{array}$ & $\begin{array}{c}0.113^{* * *} \\
(0.009)\end{array}$ \\
\hline & yes & $\begin{array}{c}0.171^{* * * *} \\
(0.006)\end{array}$ & $\begin{array}{c}0.171 * * * \\
(0.006)\end{array}$ & $\begin{array}{c}0.172 * * * \\
(0.004)\end{array}$ & $\begin{array}{c}0.121 * * * \\
(0.013)\end{array}$ & $\begin{array}{c}0.063 * * * \\
(0.012)\end{array}$ & $\begin{array}{c}0.091 * * * \\
(0.009)\end{array}$ \\
\hline & $\mathrm{N}$ & 14,725 & 20,933 & 35,658 & $\begin{array}{c}14,725 \\
{[3,555 ; 1,919]}\end{array}$ & $\begin{array}{c}20,933 \\
{[5,013 ; 2,504]}\end{array}$ & $\begin{array}{c}35,658 \\
{[8,568 ; 4,423]}\end{array}$ \\
\hline \multirow[t]{3}{*}{ B. Sons } & no & $\begin{array}{c}0.267 * * * \\
(0.009)\end{array}$ & $\begin{array}{c}0.238 * * * \\
(0.009)\end{array}$ & - & $\begin{array}{c}0.154 * * * \\
(0.019)\end{array}$ & $\begin{array}{c}0.066^{* * * *} \\
(0.018)\end{array}$ & - \\
\hline & yes & $\begin{array}{c}0.208 * * * \\
(0.010)\end{array}$ & $\begin{array}{c}0.161 * * * \\
(0.010)\end{array}$ & - & $\begin{array}{c}0.131 * * * \\
(0.019)\end{array}$ & $\begin{array}{c}0.044 * * \\
(0.018)\end{array}$ & \\
\hline & $\mathrm{N}$ & 5,645 & 7,967 & & $\begin{array}{c}5,645 \\
{[1,957 ; 1,077]}\end{array}$ & $\begin{array}{c}7,967 \\
{[2,722 ; 1,376]}\end{array}$ & \\
\hline \multirow[t]{3}{*}{ C. Daughters } & no & $\begin{array}{c}0.210 * * * \\
(0.009)\end{array}$ & $\begin{array}{c}0.233 * * * \\
(0.009)\end{array}$ & - & $\begin{array}{c}0.123 * * * \\
(0.021)\end{array}$ & $\begin{array}{c}0.090 * * * \\
(0.019)\end{array}$ & - \\
\hline & yes & $\begin{array}{c}0.144 * * * \\
(0.010)\end{array}$ & $\begin{array}{c}0.175 * * * \\
(0.010)\end{array}$ & - & $\begin{array}{c}0.103 * * * \\
(0.021)\end{array}$ & $\begin{array}{c}0.072 * * * \\
(0.019)\end{array}$ & - \\
\hline & $\mathrm{N}$ & 5,155 & 7,590 & & $\begin{array}{c}5,155 \\
{[1,805 ; 964]} \\
\end{array}$ & $\begin{array}{c}7,590 \\
{[2,599 ; 1,292]}\end{array}$ & \\
\hline
\end{tabular}

Notes: Panel A does not distinguish between whether there is a difference between if the child is a son or a daughter. Panel B reports estimates for sons, while panel C reports estimates for daughters. All regressions control for children's year of birth (and gender of child in panel A). Specifications to control for assortative mating include spousal schooling as an additional covariate. The first and second number in [.] are the number of twin pairs and the number of twin pairs with a difference in parental schooling. Robust standard errors in (.) ***significant at $1 \%, * *$ significant at $5 \%, *$ significant at $10 \%$. 
Table 3. Intergenerational associations/effects in years of schooling. Monozygotic twins. Years of schooling as of 2007 for children. Parents born 1925-65 and children born 1945-1983.

\begin{tabular}{|c|c|c|c|c|c|c|c|}
\hline & \multirow{2}{*}{$\begin{array}{c}\text { Controlling for } \\
\text { spouse's schooling }\end{array}$} & \multicolumn{3}{|c|}{ Intergenerational associations } & \multicolumn{3}{|c|}{ Intergenerational effects } \\
\hline & & $\begin{array}{l}\text { Father } \\
(1)\end{array}$ & $\begin{array}{l}\text { Mother } \\
(2)\end{array}$ & $\begin{array}{c}\text { Father+Mother } \\
\text { (3) }\end{array}$ & $\begin{array}{c}\text { Father } \\
(4)\end{array}$ & $\begin{array}{l}\text { Mother } \\
\text { (5) }\end{array}$ & $\begin{array}{c}\text { Father+Mother } \\
\text { (6) }\end{array}$ \\
\hline \multirow[t]{3}{*}{ A. Sons+daughters } & no & $\begin{array}{c}0.233 * * * \\
(0.009)\end{array}$ & $\begin{array}{c}0.234 * * * \\
(0.009)\end{array}$ & $\begin{array}{c}0.233 * * * \\
(0.006)\end{array}$ & $\begin{array}{c}0.065 * * * \\
(0.022)\end{array}$ & $\begin{array}{c}0.071 * * * \\
(0.018)\end{array}$ & $\begin{array}{c}0.069 * * * \\
(0.015)\end{array}$ \\
\hline & yes & $\begin{array}{l}0.161 * * * \\
(0.010)\end{array}$ & $\begin{array}{c}0.164 * * * \\
(0.009)\end{array}$ & $\begin{array}{c}0.164 * * * \\
(0.007)\end{array}$ & $\begin{array}{c}0.046 * * \\
(0.022)\end{array}$ & $\begin{array}{c}0.058 * * * \\
(0.018)\end{array}$ & $\begin{array}{c}0.052 * * * \\
(0.015)\end{array}$ \\
\hline & $\mathrm{N}$ & 5,403 & 7,860 & 13,263 & $\begin{array}{c}5,403 \\
{[1,309 ; 620]}\end{array}$ & $\begin{array}{c}7,860 \\
{[1,916 ; 839]}\end{array}$ & $\begin{array}{c}13,263 \\
{[3,225 ; 1,459]}\end{array}$ \\
\hline \multirow[t]{3}{*}{ B. Sons } & no & $\begin{array}{c}0.264 * * * \\
(0.015)\end{array}$ & $\begin{array}{c}0.249 * * * \\
(0.015)\end{array}$ & - & $\begin{array}{c}0.064 * * \\
(0.033)\end{array}$ & $\begin{array}{r}0.051^{*} \\
(0.30)\end{array}$ & - \\
\hline & yes & $\begin{array}{c}0.192 * * * \\
(0.016)\end{array}$ & $\begin{array}{c}0.161 * * * \\
(0.015)\end{array}$ & - & $\begin{array}{c}0.043 \\
(0.033)\end{array}$ & $\begin{array}{c}0.028 \\
(0.029)\end{array}$ & - \\
\hline & $\mathrm{N}$ & 2,053 & 3,061 & & $\begin{array}{c}2,053 \\
{[715 ; 353]}\end{array}$ & $\begin{array}{c}3,061 \\
{[1,041 ; 456]}\end{array}$ & \\
\hline \multirow[t]{3}{*}{ C. Daughters } & no & $\begin{array}{c}0.208 * * * \\
(0.015)\end{array}$ & $\begin{array}{c}0.216 * * * \\
(0.014)\end{array}$ & - & $\begin{array}{c}0.045 \\
(0.037)\end{array}$ & $\begin{array}{c}0.106 * * * \\
(0.030)\end{array}$ & - \\
\hline & yes & $\begin{array}{c}0.142 * * * \\
(0.016)\end{array}$ & $\begin{array}{c}0.157 * * * \\
(0.014)\end{array}$ & - & $\begin{array}{c}0.032 \\
(0.037)\end{array}$ & $\begin{array}{c}0.095 * * * \\
(0.030)\end{array}$ & - \\
\hline & $\mathrm{N}$ & 1,932 & 2,770 & & $\begin{array}{c}1,932 \\
{[668 ; 315]}\end{array}$ & $\begin{array}{c}2,770 \\
{[970 ; 430]}\end{array}$ & \\
\hline
\end{tabular}

Notes: Panel A does not distinguish between whether there is a difference between if the child is a son or a daughter. Panel B reports estimates for sons, while panel C reports estimates for daughters. All regressions control for children's year of birth (and gender of child in panel A). Specifications to control for assortative mating include spousal schooling as an additional covariate. The first and second number in [.] are the number of twin pairs and the number of twin pairs with a difference in parental schooling. Robust standard errors in (.) ***significant at $1 \%, * *$ significant at $5 \%, *$ significant at $10 \%$. 
Table 4. Intergenerational effects (FE). Monozygotic twin parents born 1925-1939 and 1940-1965.

\begin{tabular}{|c|c|c|c|c|c|c|c|}
\hline & \multirow{2}{*}{$\begin{array}{c}\text { Controlling for } \\
\text { spouse's schooling }\end{array}$} & \multicolumn{3}{|c|}{ Monozygotic twins born 1925-1939 } & \multicolumn{3}{|c|}{ Monozygotic twins born 1940-1965 } \\
\hline & & $\begin{array}{l}\text { Father } \\
\text { (1) }\end{array}$ & $\begin{array}{l}\text { Mother } \\
\text { (2) }\end{array}$ & $\begin{array}{c}\text { Father+Mother } \\
\text { (3) }\end{array}$ & $\begin{array}{l}\text { Father } \\
(4)\end{array}$ & $\begin{array}{l}\text { Mother } \\
\text { (5) }\end{array}$ & $\begin{array}{c}\text { Father+Mother } \\
\text { (6) }\end{array}$ \\
\hline \multirow[t]{3}{*}{ A. Sons+daughters } & no & $\begin{array}{c}0.130 * * * \\
(0.034)\end{array}$ & $\begin{array}{c}0.110 * * * \\
(0.031)\end{array}$ & $\begin{array}{c}0.119 * * * \\
(0.023)\end{array}$ & $\begin{array}{c}0.011 \\
(0.030)\end{array}$ & $\begin{array}{c}0.041 \\
(0.026)\end{array}$ & $\begin{array}{c}0.027 \\
(0.020)\end{array}$ \\
\hline & yes & $\begin{array}{c}0.099 * * * \\
(0.034)\end{array}$ & $\begin{array}{c}0.099 * * * \\
(0.030)\end{array}$ & $\begin{array}{c}0.098 * * * \\
(0.022)\end{array}$ & $\begin{array}{c}0.000 \\
(0.029)\end{array}$ & $\begin{array}{c}0.025 \\
(0.025)\end{array}$ & $\begin{array}{c}0.013 \\
(0.019)\end{array}$ \\
\hline & $\mathrm{N}$ & $\begin{array}{c}2,047 \\
{[459 ; 213]}\end{array}$ & $\begin{array}{c}2,911 \\
{[651 ; 279]}\end{array}$ & $\begin{array}{c}4,958 \\
{[1,110 ; 492]}\end{array}$ & $\begin{array}{c}3,356 \\
{[850 ; 407]}\end{array}$ & $\begin{array}{c}4,949 \\
{[1,265 ; 560]}\end{array}$ & $\begin{array}{c}8,305 \\
{[2,115 ; 967]}\end{array}$ \\
\hline \multirow[t]{3}{*}{ B. Sons } & no & $\begin{array}{c}0.145^{* * *} * \\
(0.051)\end{array}$ & $\begin{array}{c}0.158 * * * \\
(0.049)\end{array}$ & - & $\begin{array}{c}-0.013 \\
(0.043)\end{array}$ & $\begin{array}{l}-0.031 \\
(0.038)\end{array}$ & - \\
\hline & yes & $\begin{array}{c}0.106 * * \\
(0.053)\end{array}$ & $\begin{array}{c}0.140 * * * \\
(0.048)\end{array}$ & - & $\begin{array}{l}-0.019 \\
(0.042)\end{array}$ & $\begin{array}{l}-0.060 \\
(0.036)\end{array}$ & - \\
\hline & $\mathrm{N}$ & $\begin{array}{c}782 \\
{[263 ; 125]}\end{array}$ & $\begin{array}{c}1,127 \\
{[366 ; 156]}\end{array}$ & & $\begin{array}{c}1,271 \\
{[452 ; 228]}\end{array}$ & $\begin{array}{c}1,934 \\
{[675 ; 300]}\end{array}$ & \\
\hline \multirow[t]{3}{*}{ C. Daughters } & no & $\begin{array}{c}0.077 \\
(0.062)\end{array}$ & $\begin{array}{r}0.097 * * \\
(0.047)\end{array}$ & - & $\begin{array}{c}0.028 \\
(0.046)\end{array}$ & $\begin{array}{c}0.110 * * * \\
(0.040)\end{array}$ & - \\
\hline & yes & $\begin{array}{c}0.057 \\
(0.061)\end{array}$ & $\begin{array}{l}0.084^{*} \\
(0.046)\end{array}$ & - & $\begin{array}{c}0.022 \\
(0.046)\end{array}$ & $\begin{array}{c}0.100 * * * \\
(0.039)\end{array}$ & - \\
\hline & $\mathrm{N}$ & $\begin{array}{c}748 \\
{[243 ; 108]}\end{array}$ & $\begin{array}{c}1,119 \\
{[367 ; 153]}\end{array}$ & & $\begin{array}{c}1,184 \\
{[425 ; 207]}\end{array}$ & $\begin{array}{c}1,651 \\
{[603 ; 277]}\end{array}$ & \\
\hline
\end{tabular}

Notes: Panel A does not distinguish between whether there is a difference between if the child is a son or a daughter. Panel B reports estimates for sons, while panel C reports estimates for daughters. All regressions control for children's year of birth (and gender of child in panel A). Specifications to control for assortative mating include spousal schooling as an additional covariate. The first and second number in [.] are the number of twin pairs and the number of twin pairs with a difference in parental schooling. Robust standard errors in (.) $* * *$ significant at $1 \%$, **ignificant at $5 \%$, *significant at $10 \%$. 


\section{Appendix}

Table A1. Intergenerational effects (FE). Mono- and dizygotic twins parents born 1925-1939 and 1940-1965.

\begin{tabular}{|c|c|c|c|c|c|c|c|}
\hline & \multirow{2}{*}{$\begin{array}{c}\text { Controlling for } \\
\text { spouse's schooling }\end{array}$} & \multicolumn{3}{|c|}{ Mono- and dizygotic twins born 1925-1939 } & \multicolumn{3}{|c|}{ Mono- and dizygotic twins born 1940-1965 } \\
\hline & & $\begin{array}{c}\text { Father } \\
(1)\end{array}$ & $\begin{array}{l}\text { Mother } \\
(2)\end{array}$ & $\begin{array}{l}\text { Father+Mother } \\
\text { (3) }\end{array}$ & $\begin{array}{c}\text { Father } \\
(4)\end{array}$ & $\begin{array}{l}\text { Mother } \\
\text { (5) }\end{array}$ & $\begin{array}{l}\text { Father+Mother } \\
\text { (6) }\end{array}$ \\
\hline \multirow[t]{3}{*}{ A. Sons+daughters } & no & $\begin{array}{c}0.168 * * * \\
(0.020)\end{array}$ & $\begin{array}{c}0.081 * * * \\
(0.019)\end{array}$ & $\begin{array}{c}0.124 * * * \\
(0.014)\end{array}$ & $\begin{array}{c}0.130 * * * \\
(0.017)\end{array}$ & $\begin{array}{c}0.083 * * * \\
(0.015)\end{array}$ & $\begin{array}{c}0.104 * * * \\
(0.011)\end{array}$ \\
\hline & yes & $\begin{array}{c}0.137 * * * \\
(0.020)\end{array}$ & $\begin{array}{c}0.065 * * * \\
(0.019)\end{array}$ & $\begin{array}{c}0.101 * * * \\
(0.014)\end{array}$ & $\begin{array}{c}0.106 * * * \\
(0.017)\end{array}$ & $\begin{array}{c}0.060 * * * \\
(0.015)\end{array}$ & $\begin{array}{c}0.081 * * * \\
(0.011)\end{array}$ \\
\hline & $\mathrm{N}$ & $\begin{array}{c}5,835 \\
{[1,299 ; 674]}\end{array}$ & $\begin{array}{c}8,399 \\
{[1,854 ; 894]}\end{array}$ & $\begin{array}{c}14,234 \\
{[3,153 ; 1,568]}\end{array}$ & $\begin{array}{c}8,890 \\
{[2,256 ; 1,245]}\end{array}$ & $\begin{array}{c}12,534 \\
{[3,159 ; 1,610]}\end{array}$ & $\begin{array}{c}21,424 \\
{[5,415 ; 2,855]}\end{array}$ \\
\hline \multirow[t]{3}{*}{ B. Sons } & no & $\begin{array}{c}0.185 * * * \\
(0.026)\end{array}$ & $\begin{array}{c}0.084 * * * \\
(0.030)\end{array}$ & - & $\begin{array}{c}0.125 * * * \\
(0.027)\end{array}$ & $\begin{array}{c}0.053 * * \\
(0.022)\end{array}$ & - \\
\hline & yes & $\begin{array}{c}0.156 * * * \\
(0.028)\end{array}$ & $\begin{array}{c}0.061 * * \\
(0.030)\end{array}$ & - & $\begin{array}{c}0.107 * * * \\
(0.027)\end{array}$ & $\begin{array}{c}0.029 \\
(0.022)\end{array}$ & - \\
\hline & $\mathrm{N}$ & $\begin{array}{c}2,279 \\
{[752 ; 401]}\end{array}$ & $\begin{array}{c}3,222 \\
{[1,052 ; 515]}\end{array}$ & & $\begin{array}{c}3,366 \\
{[1,205 ; 676]}\end{array}$ & $\begin{array}{c}4,745 \\
{[1,670 ; 861]}\end{array}$ & \\
\hline \multirow[t]{3}{*}{ C. Daughters } & no & $\begin{array}{c}0.148 * * * \\
(0.033)\end{array}$ & $\begin{array}{c}0.074 * * * \\
(0.029)\end{array}$ & - & $\begin{array}{c}0.108 * * * \\
(0.028)\end{array}$ & $\begin{array}{c}0.101 * * * \\
(0.025)\end{array}$ & - \\
\hline & yes & $\begin{array}{c}0.124 * * * \\
(0.033)\end{array}$ & $\begin{array}{c}0.061 * * \\
(0.029)\end{array}$ & - & $\begin{array}{c}0.090 * * * \\
(0.027)\end{array}$ & $\begin{array}{c}0.079 * * * \\
(0.024)\end{array}$ & - \\
\hline & $\mathrm{N}$ & $\begin{array}{c}2,084 \\
{[698 ; 356]}\end{array}$ & $\begin{array}{c}3,187 \\
{[1,030 ; 479]} \\
\end{array}$ & & $\begin{array}{c}3,071 \\
{[1,107 ; 608]}\end{array}$ & $\begin{array}{c}4,403 \\
{[1,569 ; 813]} \\
\end{array}$ & \\
\hline
\end{tabular}

Notes: Panel A does not distinguish between whether there is a difference between if the child is a son or a daughter. Panel B reports estimates for sons, while panel C reports estimates for daughters. All regressions control for children's year of birth (and gender of child in panel A). Specifications to control for assortative mating include spousal schooling as an additional covariate. The first and second number in [.] are the number of twin pairs and the number of twin pairs with a difference in parental schooling. Robust standard errors in (.) ***significant at $1 \%, * *$ significant at $5 \%, *$ significant at $10 \%$ 
Table A2: Effect of father's and mother's years of schooling on number of children and spouse's years of schooling. MZ twins born 1925-1965

\begin{tabular}{|c|c|c|c|c|}
\hline & Number o & Children & Twin Spouse & ears of Schooling \\
\hline & $\begin{array}{l}\text { Mother } \\
\text { (1) }\end{array}$ & $\begin{array}{l}\text { Father } \\
\text { (2) }\end{array}$ & $\begin{array}{l}\text { Father } \\
\text { (3) }\end{array}$ & $\begin{array}{l}\text { Mother } \\
\text { (4) }\end{array}$ \\
\hline A. Sons + Daughters & $\begin{array}{l}-0.011 \\
(0.007)\end{array}$ & $\begin{array}{l}-0.017 * * \\
(0.008)\end{array}$ & $\begin{array}{l}0.116 * * * \\
(0.017)\end{array}$ & $\begin{array}{l}0.149 * * * \\
(0.019)\end{array}$ \\
\hline $\mathrm{N}$ & $\begin{array}{c}7,806 \\
{[1,916 ; 839]}\end{array}$ & $\begin{array}{c}5,403 \\
{[1,309 ; 620]}\end{array}$ & $\begin{array}{l}7,806 \\
{[1,916 ; 839]}\end{array}$ & $\begin{array}{l}5,403 \\
{[1,309 ; 620]}\end{array}$ \\
\hline B. Sons & $\begin{array}{l}-0.027 * * \\
(0.013)\end{array}$ & $\begin{array}{l}-0.011 \\
(0.014)\end{array}$ & $\begin{array}{l}0.143 * * * \\
(0.028)\end{array}$ & $\begin{array}{l}0.169 * * * \\
(0.032)\end{array}$ \\
\hline $\mathrm{N}$ & $\begin{array}{c}3,061 \\
{[1,041 ; 456]}\end{array}$ & $\begin{array}{l}2,053 \\
{[715 ; 353]}\end{array}$ & $\begin{array}{l}3,061 \\
{[1,041 ; 456)}\end{array}$ & $\begin{array}{l}2,053 \\
{[715 ; 353]}\end{array}$ \\
\hline C. Daughters & $\begin{array}{c}0.001 \\
(0.013)\end{array}$ & $\begin{array}{c}-0.012 \\
(0.016)\end{array}$ & $\begin{array}{l}0.128 * * * \\
(0.030)\end{array}$ & $\begin{array}{l}0.101 * * * \\
(0.035)\end{array}$ \\
\hline $\mathrm{N}$ & $\begin{array}{c}2,770 \\
{[970 ; 430)}\end{array}$ & $\begin{array}{c}1,932 \\
{[668: 315]}\end{array}$ & $\begin{array}{l}2,770 \\
{[970 ; 430]}\end{array}$ & $\begin{array}{l}1,932 \\
[668 ; 315])\end{array}$ \\
\hline
\end{tabular}

Note: All estimates are from within-twins regressions. Panel A reports estimates for all twin mothers. Panel B reports estimates for twin mothers with sons, while panel $\mathrm{C}$ reports estimates for twin mothers with daughters. The first and second number in [.] are the number of twin pairs and the number of twin pairs with a difference in parental schooling. Robust standard errors in (.) ***significant at $1 \%, * *$ significant at $5 \%, *$ significant at $10 \%$. 